https://doi.org/10.15407/scine17.04.019

SMIRNOV, O. M. (https://orcid.org/0000-0003-1173-976X), NARIVSKIY, A. V (https://orcid.org/0000-0002-1596-6401),

SMIRNOV, E. N. (https://orcid.org/0000-0002-4948-1031),

VERZILOV, A. P. (https://orcid.org/0000-0003-0463-5006),

SEMENKO, A. Yu. (https://orcid.org/0000-0002-0448-1636),

and GORYUK, M. S. (https://orcid.org/0000-0002-7561-6948)

Physico-Technological Institute of Metals and Alloys,

the NAS of Ukraine (PTIMA of the NAS of Ukraine),

34/1, Acad. Vernadsky Blvd, Kyiv, 03142, Ukraine,

+380 44 424 3515, metal (c)ptima. kiev.ua

\title{
DEVELOPMENT OF A TWO-CHAMBER MHD TUNDISH FOR METAL CASTING
}

Introduction. The multifunctional magnetodynamic tundish prototype is the first world magnetodynamic mixer and batcher for steel, which has a capacity of up to 10 tons of melt and an inductor electric power of $600 \mathrm{~kW}$. It has been successfully introduced into industry. Further works aim at adapting this device to continuous casting, in particular at obtaining semi-continuous cast billets at metallurgical micro-plants.

Problem Statement. Today, the study of the effect of electromagnetic field on melt stirring and removal of non-metallics in the inlet chamber of $M D$-T is an urgent task.

Purpose. The purpose of this research is to substantiate and to create $M D-T$ as a two-chamber aggregate additionally equipped with a few electromagnetic $\mathcal{E}$ MHD devices for different purposes, to be used at metallurgical micro-mills.

Materials and Methods. Physical modelling has been applied for studying liquid metal stirring under the action of electromagnetic field and the removal of non-metallics.

Results. The behavior of the liquid jet falling from the ladle into the centrifugal chamber has been studied. The influence of the rational liquid level in the centrifugal chamber, which is exposed to the direct action of the electromagnetic field, has been estimated. It has been established that the effect of rotation of the total liquid volume has been achieved at the height of application of electromagnetic field, which is 0.2-0.3 of the total fill height. Increasing the height of the application of a magnetic field leads to the capture of the upper layers of the liquid.

Conclusions. There have been proposed a new design of magnetodynamic tundish $(M D-T)$ for continuous casting of steel. The use of tundish with a rotational motion of the flow may significantly reduce the number of large oxide inclusions (larger than $10 \mu \mathrm{m}$ ) in steel. The device has been successfully tested and its application will improve the quality of cast billets, extend the functionality of equipment and technologies, and enable the realization of modern high-efficiency processes of continuous casting.

Keywords: continuous casting, electromagnetic stirring $\mathcal{E}$ pouring, magnetodynamic tundish, non-metallics, and physical model.

Citation: Smirnov, O. M., Narivskiy, A. V., Smirnov, E. N., Verzilov, A. P., Semenko, A.Yu., and Goryuk, M. S. Development of a Two-Chamber MHD Tundish for Metal Casting. Sci. innov. 2021. V. 17, no. 4. P. 19-24. https://doi.org/10.15407/scine17.04.019 
In recent years, the application of specialized MHDdevices for continuous casting of metals has been studied in the PTIMA of the NAS of Ukraine.

There has been offered a new multifunctional magnetodynamic tundish (MD-T) for continuous casting of steel [1]. Its prototype is the first world magnetodynamic mixer and batcher for steel. It has a capacity to 10 tons of melt and an inductor electric power of $600 \mathrm{~kW}$. It has been successfully introduced into industry.

Further research aims at adapting the device to the requirements for continuous and semi-continuous casting [2-7] and at preparing billets at metallurgical micro-plants [8-10].

The new MD-T may be designed as two-chamber aggregate (Fig.1). In this case, it consists of the inlet chamber to which the melt is supplied from the steel ladle and the pouring chamber where liquid metal is discharged into the mold of continuous casting machine (CCM). The pouring chamber of the MD-T consists of induction channels (2, 3 or 4$)$ where the alternating electric current is induced and thus the melt is heated directly while pouring into the mold of continuous casting machine (CCM). Additionally, in the induction channels, there are placed the electromagnets that create external alternating magnetic field interacting with induction current and generating the volume electromagnetic force. It allows controlling the melt flow during stirring and pouring (in this case, electromagnets may slow down or accelerate the melt stream).

Moreover, the MD-T may be equipped with specialized electromagnetic and MHD devices. So, it is possible to set an electromagnetic stirrer on the inlet chamber sidewall. The stirrer may provide physical effect of different types of alternating magnetic field (pulsating, alternating, rotating) on liquid metal [11]. In turn, it is possible to install an MHD-device for other purposes on the pouring chamber. It enables the control of the mass flow rate, width, and direction of the flat melt flow during its pouring.

Statement of the problem. The purpose of this research is studying the effect of electromagne-

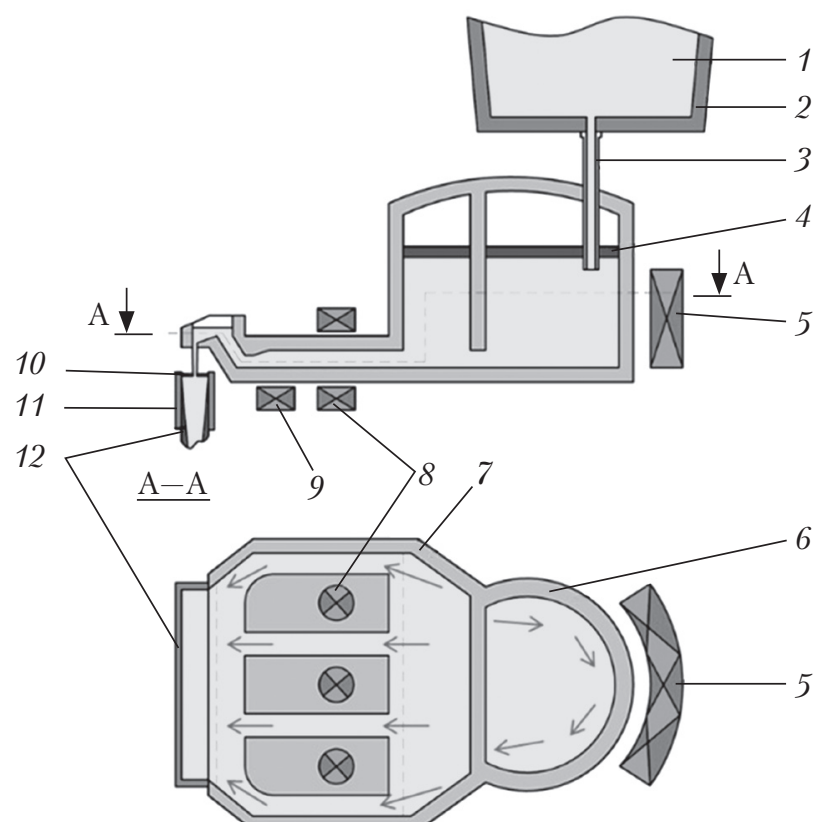

Fig. 1. General view of the two-chamber magnetodynamic tundish equipped with additional electromagnetic devices: 1 - liquid metal; 2 - steel teeming ladle; 3 - pouring nozzle; 4 - covering slag; 5 - electromagnetic stirrer; 6 - inlet chamber; 7 - pouring chamber; 8 - inductors; 9 - electromagnet; 10 - slag-forming mix; 11 - CCM mold; $12-$ solidifying ingot

tic field on melt stirring and removal of non-metallics in the inlet chamber of MD-T.

The developed multifunctional electromagnetic stirrer has been used [4-6]. Its electric power is ca. $20 \mathrm{~kW}$. Such stirrer has been studied by mathematical modelling methods [5, 12]. It enables alternate action of rotating and pulsating magnetic fields. While studying the designed semicircular inlet chamber of MD-T, it has been established that the rotating motion of melt is realized.

The stirrer efficiency and the adequacy of stirrer mathematical model have been confirmed by the experiments with liquid aluminum alloys in magnetodynamic device.

For studying the continuous casting with the use of two-chamber MD-T, there has been developed a physical model with imitation of electromagnetic stirring (Fig. 2). This model has allowed solving the following tasks: 
- to study the effect of metal rotation under electromagnetic stirring in the centrifugal chamber of the MD-T;

- to determine the rational height, electromagnetic field application, and the speed of rotation of the liquid bath;

- to study the features of the transformation of the melt jet falling from the steel teeming ladle into the centrifugal chamber;

- to study the distribution of non-metallics in the melt volume in the centrifugal chamber and the speed of their floating-up, depending on the speed of rotation of the melt, and to compare the efficiency of the removal of non-metallics in the case of two-chamber MD-T with the use of electromagnetic forces with that in the case of various refining operations in conventional tundishes;

- to assess the possibility of vortex phenomena in the centrifugal chamber volume.

Water is used as a modelling fluid. The covering slag on the metal surface in the tundish is simulated is modelled by silicone oil. Melt stirring under the action of electromagnetic field is simulated with the use of a pump that triggers directed rotation. The behavior of non-metallics is simulated and visualized by plastic balls with different diameters. Additionally, the formed streams are visualized by ink coloring of local fluid volumes. The hydrodynamic picture is recorded by digital video equipment.

During the motion of a modelling fluid, under the action of gravity, there are the processes that cause the non-metallics to rise and the inertia forces that determine the development of a system of circulation flows in a liquid bath of the centrifugal chamber of the tundish. So, the Froude and homochronism criteria are taken as the basic similarity criteria.

The following results have been obtained.

1. The behavior of the jet of liquid falling from the ladle into the centrifugal chamber has been studied. The rotational motion contributes to the slowdown and destruction of high-speed jet. The effect of fluid homogenization in the tundish is determined by the speed of rotation, which is equal to 5-10 rpm (Fig. 3).

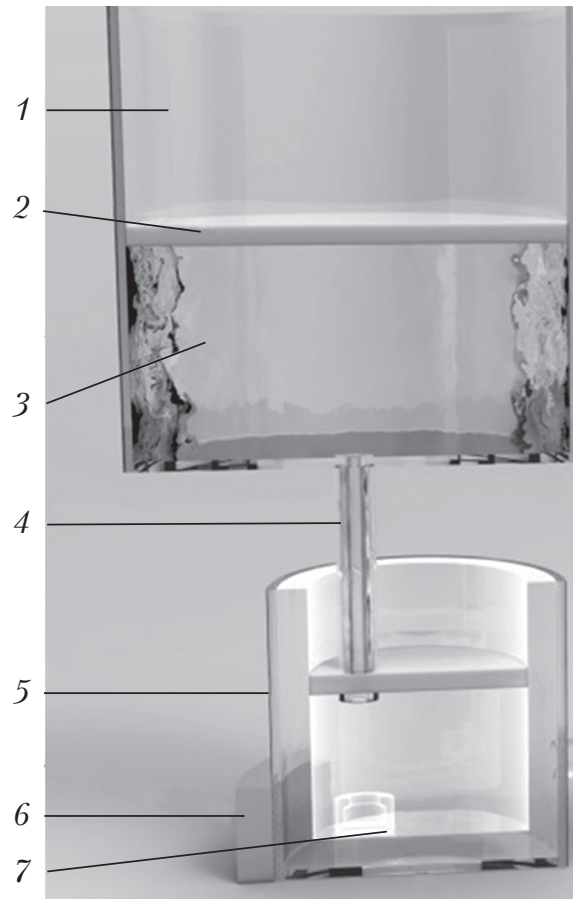

Fig. 2. Physical model for studying metal flow in two-chamber MD-T: 1 - ladle; 2 - slag; 3 - modeling fluid; 4 - nozzle; 5 - centrifugal chamber; 6 - pump to simulate rotation; 7 - metal receiver

2. The influence of the rational liquid level in the centrifugal chamber, which is exposed to the direct action of the electromagnetic field has been estimated. It has been established that the effect of rotating the whole volume of liquid is achieved at a height of application of electromagnetic field, which is equal to $0.2-0.3$ of the total fill height. Increasing the height of the application of a magnetic field leads to the capture of the upper layers of the liquid. This may cause an additional contamination of steel with top slag particles.

3. Due to the rotation of liquid steel, the time of its stay in the tundish increases. So, the possibility of removing large non-metallics increases as a result of their floating-up into the slag. Accordingly, the refining capacity of this tundish is larger than that of the usual tundishes. The use of tundish with rotating flow may significantly reduce the number of large oxide inclusions (larger than $10 \mu \mathrm{m}$ ) in steel. 

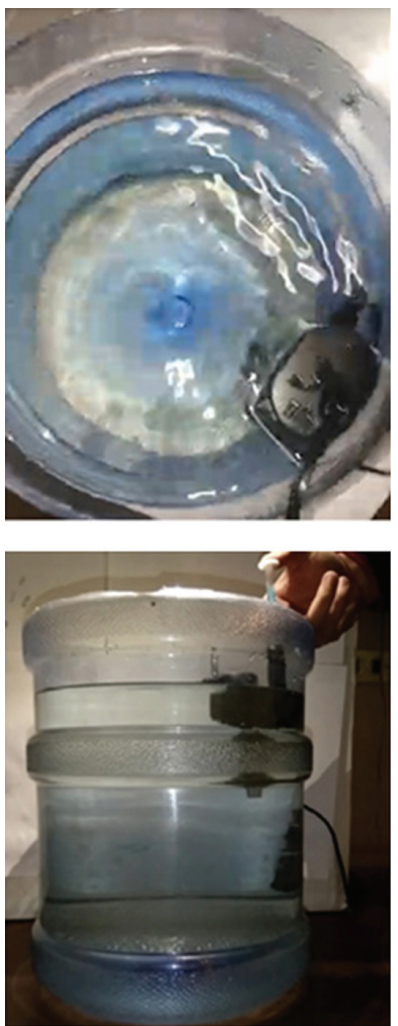

Time: $0 \mathrm{~s}$
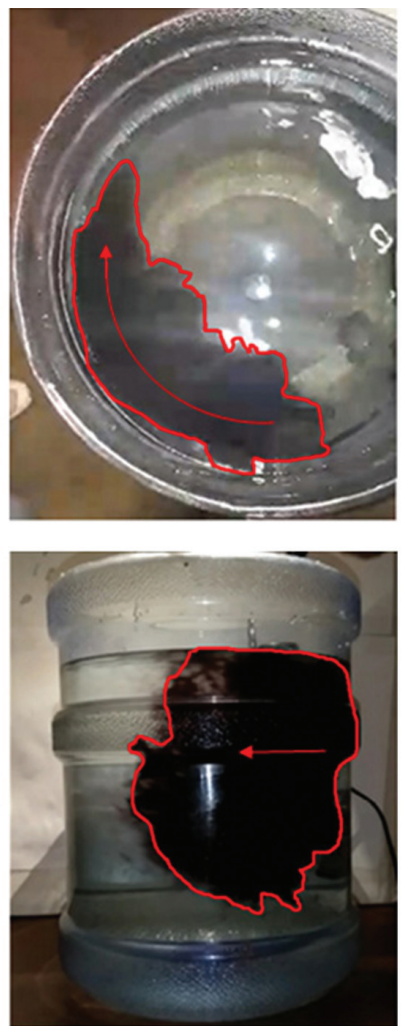

$3 \mathrm{~s}$
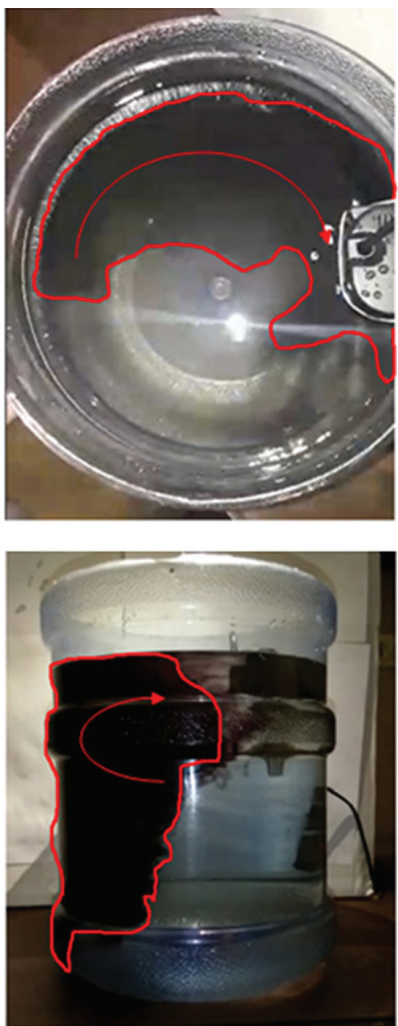

$6 \mathrm{~s}$
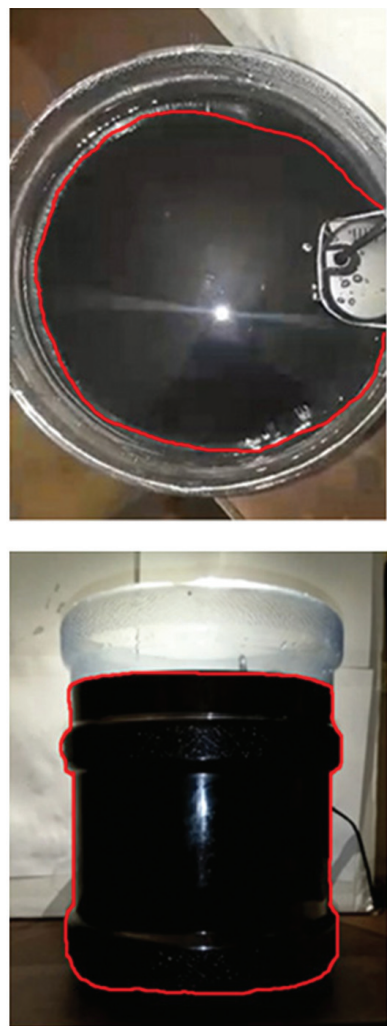

$9 \mathrm{~s}$

Fig. 3. Physical modeling for study fluid homogenization in two-chamber MD-T (the formed water streams is visualized by ink coloring): $a$ - top view; $b$ - front view
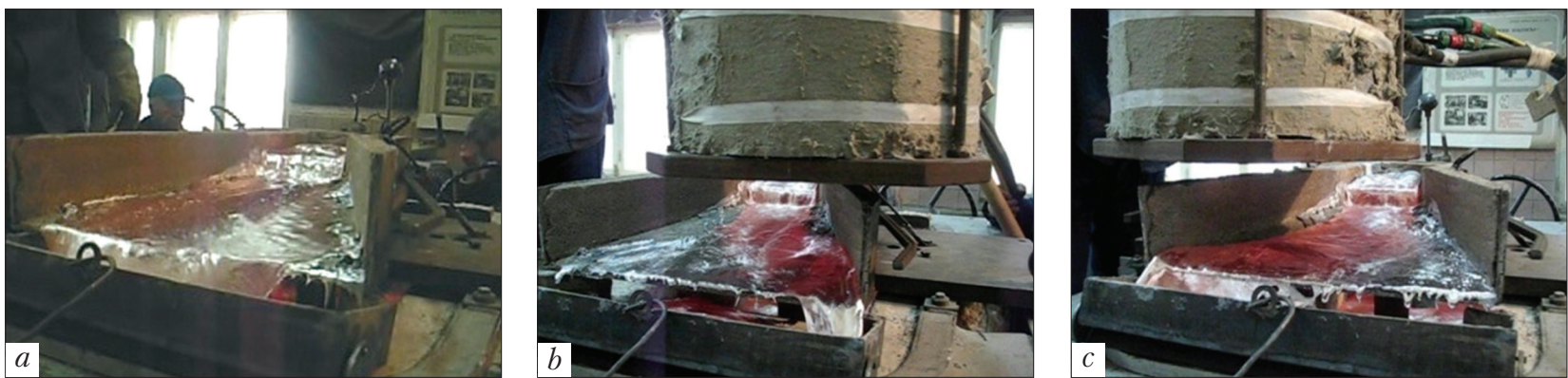

Fig. 4. Action of external magnetic field generated by specialized MHD-device on the formation of flat stream of aluminum melt in trunk in the case of electromagnetic pouring from magnetodynamic device $(a)$ and change in the direction of melt flow $(b, c)$

The next stage of research deals with the application of electromagnetic field while pouring melt.

There has been made a specialized MHD-device for distribution of melt on pouring trunk and forming a flat stream. The efficiency of this device has been confirmed by the experiment with liquid aluminum alloy. The melt is poured from magnetodynamic device under the action of electromagnetic force. As a result, melt stream under the action of magnetic field is dispersed through the trunk width (Fig. 4, $a$ ). The electromagnetic system is placed above the trunk and stimulates 
the flow spread across the width and, should the need arise to shift the pouring section, along om the edge of trunk (Fig. 4, $b, c$ ).

The possibility of electromagnetic pouring of melt by a wide flat stream into a thin-slab crystallizer of CCM or into a gap between the rolls of two-roll casting and rolling machine has been demonstrated.

Conclusions. New design of magnetodynamic tundish (MD-T) for continuous casting of steel, namely two-chamber configuration of MD-T equipped with a few specialized electromagnetic units and MHD-devices for heating, stirring. and pouring melt has been proposed.
Such devices have been designed, studied, and successfully tested.

As a result, it is possible to improve the quality of cast billets, to extend the functionality of equipment and technologies, and to realize the modern high-efficiency processes of continuous casting.

Funding of the research. The research has been conducted at the Physics and Technology Institute of Metals and Alloys of the NAS of Ukraine, within the framework of NDR III-09-17-671 project The Development of the Scientific Framework for Creating New Highly Efficient Multifunctional Magnetodynamic Intermediate Ladles for Continuous Casting Processes.

\section{REFERENCES}

1. Wang, E. (2015). Progress of some techniques on electromagnetic metallurgy. Proceedings of the 8th International Conference on Electromagnetic Processing of Materials "EPM 2015. (October 12-16, 2015). Cannes, 3-6.

2. Sivak, B. A., Shakhov, S. I., Vdovin, K. N., Rogachikov Yu. M., Kerimov R. I. (2020). Development of a System for Electromagnetic Stirring of Liquid Steel in Molds of Billet and Bloom CCMS. Metallurgist, 63, 910-914. https://doi. org/10.1007/s11015-020-00909-w

3. Fang, Q., Zhang, H., Wang, J., Liu, C., Ni, H. (2020). Effect of Electromagnetic Stirrer Position on Mold Metallurgical Behavior in a Continuously Cast Bloom. Metall and Materi Trans B, 51, 1705-1717. https://doi.org/10.1007/s11663020-01849-1

4. Maurya, A., Kumar Jha, P. (2018). Study of Fluid Flow and Solidification in Billet Caster Continuous Casting Mold with Electromagnetic Stirring. Archives of Metallurgy and Materials, 63 (1), 413-424. https://doi.org/10.24425/118955.

5. Dubodelov, V. Y., Smyrnov, A. N., Efymova, V. H., Kravchenko, A. V., Verzylov, A. P. (2018). Hydrodynamic and physicochemical processes in tundishes for continuous casting of steel. Kyiv: Naukova dumka, 264 [in Russian].

6. Cho, S.-M.; Thomas, B. G. (2019). Electromagnetic Forces in Continuous Casting of Steel Slabs. Metals, 9, 471. https:// doi.org/10.3390/met9040471.

7. Dubodelov, V., Semenko, A., Bogdan, K., Goryuk, M. (2019). Development of Principles to Control the Processes of Continuous Casting of Alloys Using Magnetodynamic Equipment. Eastern-European Journal of Enterprise Technologies, 4(1(100)), 69-75. https://doi.org/10.15587/1729-4061.2019.172051.

8. Smirnov, A. N., Khobta, A. S., Smirnov, E. N., Serov, A. I., Verzilov, A. P. (2012). Casting of steel from the tundish of a continuous caster with a sliding gate. Russian Metallurgy, 12, 1-5 [in Russian]. https://doi.org/10.1134/S0036029512120166.

9. Lubenets, A. N., Smirnov, E. N., Shcherbachev, V. V. (2002). Production of ship sections from continuous casting billets. Stal, 8, 102-106 [in Russian].

10. Smirnov, A. N., Spiridonov, D. V., Verzilov, A. P., Golovatyi, V. A., Goida, D. I.. (2014). Effect of the design of a supply nozzle on the ingot formation during semicontinuous casting of copper. Russian Metallurgy (Metally), 474-478 [in Russian]. https://doi.org/10.1134/S0036029514060147

11. Goman, V., Sokolov, I., Fedoreev, S. (2019). Modeling Electromagnetic Stirring Processes during Continuous Casting of Large-format Slabs. International Conference on Industrial Engineering, Applications and Manufacturing (ICIEAM), 2019, 1-5. Sochi, Russia. https://doi.org/10.1109/ICIEAM.2019.8743005.

12. Horiuchi, S., Uddin, M. A., Kato, Y., Kikuchi, N. (2014). Liquid / liquid Mixing Pattern in a Mechanically-stirred Vessel. ISIJ International, 54, 1, 82-86. https://doi.org/10.2355/isijinternational.54.82

Received 07.09.2020

Revised 22.12.2020

Accepted 29.03.2021 
O.M. Смірнов (https://orcid.org/0000-0003-1173-976X),

А.В. Нарівський (https://orcid.org/0000-0002-1596-6401),

C.M. Смірнов (https://orcid.org/0000-0002-4948-1031),

О.П. Верзілов (https://orcid.org/0000-0003-0463-5006),

А.Ю. Семенко (https://orcid.org/0000-0002-0448-1636),

М.С. Горюк (https://orcid.org/0000-0002-7561-6948)

Фізико-технологічний інститут металів та сплавів

Національної академії наук України (ФТІМС НАН України),

бульв. Вернадського, 34/1, Київ, 03142, Україна,

+380444243515, metal@ptima.kiev.ua

\section{РОЗРОБКА ДВОКАМЕРНОГО МГД ПРОМІЖНОГО КОВША ДЛЯ РОЗЛИВАННЯ МЕТАЛІВ}

Вступ. Прототипом багатофункціонального магнітодинамічного проміжного ковша (МД-ПК) є перший у світі магнітодинамічний міксер-дозатор для сталі місткістю до 10 т розплаву та електричною потужністю індукторів 600 кВт. Двокамерний МД-ПК було успішно впроваджено у промисловість. Подальші дослідження спрямовано на адаптацію цього пристрою для безперервного лиття сталі, зокрема на отримання напівперервних литих заготовок на металургійних мікрозаводах.

Проблематика. Вивчення впливу електромагнітного поля на перемішування розплаву та видалення неметалічних включень у прийомній камері МД-ПК на сьогодні є актуальним завданням.

Мета. Обгрунтування та створення МД-ПК для роботи в умовах металургійних мікрозаводів, як двокамерного агрегату, що додатково оснащено кількома електромагнітними та магнітодинамічними (МГд) пристроями.

Матеріали й методи. Вивчення процесу перемішування рідких металів під дією електромагнітного поля та видалення неметалевих домішок реалізовано за допомогою фізичного моделювання.

Результати. Вивчено поведінку струменя моделюючої рідини, що потрапляє зі сталерозливного ковша в центрифужну камеру. Оцінено вплив раціонального рівня рідини в центрифужній камері, що піддається прямій дії електромагнітного поля. Встановлено, що ефект обертання загального об'єму рідини досягається вже на висоті застосування електромагнітного поля, що дорівнює $0,2-0,3$ від загального рівня заповнення. Збільшення висоти накладення магнітного поля призводить до захоплення верхніх шарів моделюючої рідини.

Висновки. Запропоновано нову конструкцію магнітодинамічного проміжного ковша (МД-ПК) для безперервного розливання сталі. Застосування МД-ПК з обертовим рухом потоку може значно зменшити кількість великих оксидних включень у сталі (більше 10 мкм). Пристрій було успішно апробовано, а його застосування дозволить покращити якість литих злитків, розширити функціональність обладнання та технологій, реалізувати сучасні високоефективні процеси безперервного лиття.

Ключові слова: безперервне лиття, електромагнітне перемішування та розливання, магнітодинамічний проміжний ківш, неметалеві включення, фізична модель. 